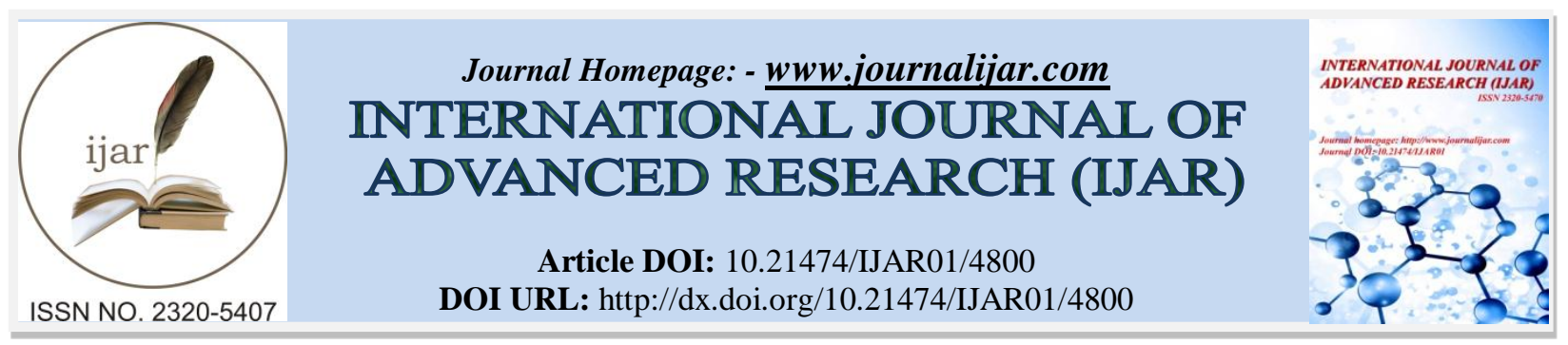

RESEARCH ARTICLE

\title{
THE RIGHTS OF UNLAWFUL ARREST VICTIMS TO DEMAND FOR COMPENSATION IN INDONESIAN CRIMINAL JUSTICE SYSTEM.
}

Rini Ariani Said.

Graduate School, Faculty of Law, Hasanuddin University, Indonesia.

\section{Manuscript Info}

\section{Manuscript History}

Received: 10 May 2017

Final Accepted: 12 June 2017

Published: July 2017

Key words:-

Victim, Unlawful Arrest, Compensation,

Indonesian Criminal Justice System

\section{Abstract}

A person's right to demand compensation for unlawful arrest is a basic right guaranteed by the law. This basic right is owned by every citizen and guaranteed by the government. This research aims to analyze the compensation mechanisms for unlawful arrest victims. The method used in this research is sociological jurisprudence, a study based on library research as well as field research. The outcome of the research indicates that Government Regulation No. 92 of 2015 has been present as a legal protection for unlawful arrest victims with significant changes in the amount of compensation but unfortunately until now it has not complemented with rules on payment mechanism of compensation. The Ministry of Finance of the Republic of Indonesia should immediately review Indonesian Regulation on the Payment Mechanism of Compensation because it is no longer applicable in accordance with some other rules in Indonesia.

Copy Right, IJAR, 2017,. All rights reserved.

\section{Introduction:-}

Since 1981 the rules of Indonesian Criminal Justice System has officially changed from HIR (Hit Herziene Indonesisch Reglement) No. 44 of 1941 into Law No. 8 of 1981 on Criminal Law Code (hereinafter referred as KUHAP). ${ }^{1}$ KUHAP is expected to serve as a guideline for conducting justice for the courts within the general court and the Supreme Court by regulating the rights and obligations of those in the criminal process, so that the basis of the law state can be upheld. KUHAP shall be based on the nation's philosophy/ philosophy of life and the foundation of the state, so that its articles shall reflect the protection of human rights and the obligations of the citizens in a state law as well as the principles of protection pursuant to Law No. 14 of 1970 on The Principal of Judicial Power jo. Law No. 35 of 1999 with the amendment Law No. 48 of 2009. The principles are: (a) Equal treatment of each person before the law and non-discrimination; (b) Arrests, detentions, searches and seizures are made only by written order by officials authorized by law and only in cases and in the manner prescribed by law; (c) Anyone suspected, arrested, detained, prosecuted and or brought before a court of law, shall be presumed innocent until a court decision declares his guilt and obtains a permanent legal force; (d) To a person who is arrested, detained, prosecuted or tried without reason based on law and / or due to errors concerning the person or applicable law shall be compensated and rehabilitated from the level of investigation and law enforcement officials intentionally or by reason of His negligence causes the legal principle to be violated, prosecuted, punishable and or subject to administrative punishment; (e) A judgment which shall be made promptly, simply and lightly and freely, honestly and impartially shall be applied consequently at all levels of the judiciary; (f) Every person who is involved in a case

1 State Gazette Number 76 of 1981, State Gazette supplement Number 3209, December 31 of 1981 
shall be given the opportunity to obtain legal assistance solely given to carry out the interests of his or her defense; (g) To a suspect, from the moment of arrest and/ or detention other than shall be informed of the indictment and legal basis of the indicted, to him, shall also be informed of his rights including the right to contact and seek the assistance of legal counsel; (h) The court shall examine the criminal case in the presence of the defendant; (i) The court hearing is open to the public except in matters governed by law; and (j) Supervision of the execution of a court decision in a criminal case shall be stipulated by the chair of the relevant district court.

In connection with the principle of letter ' $d$ ', it is clear that Indonesian law protects the victim of unlawful arrest in this case the law ensures to provide compensation and rehabilitation to victims of unlawful arrest. Legal protection of victims of crime is not only a national issue but also an international issue ${ }^{2}$ as its regulated on Declaration of Basic Principles of Justice for Victims of Crime and Abuse of Power by United Nations, as the result of The Seventh United Nation Congress on the Prevention of Crime and the Treatment of Offenders. Based on Declaration of Basic Principles of Justice for Victims of Crime and Abuse of Power, The form of protection is not only aimed at victims of crime, but also protection of victims due to abuse of power. Victims means persons who, individually or collectively, have suffered harm, including physical or mental injury, emotional suffering, economic loss or substantial impairment of their fundamental rights, through acts or omissions that are in violation of criminal laws operative within Member States, including those laws proscribing criminal abuse of power. ${ }^{3}$ While Victims of abuse of power means persons who, individually or collectively, have suffered harm, including physical or mental injury, emotional suffering, economic loss or substantial impairment of their fundamental rights, through acts or omissions that do not yet constitute violations of national criminal laws but of internationally recognized norms relating to human rights. 4

The investigator in making the arrest must fully fulfill the applicable provisions. There are two conditions to be met by investigators when making arrests based on Article 17 of KUHAP: (1) A suspect who likes to commit a crime; And (2) The strong suspicion must be built at the beginning of sufficient evidence. The meaning of sufficient preliminary evidence is a preliminary proof for the alleged existence of a criminal offense, among others, a sample

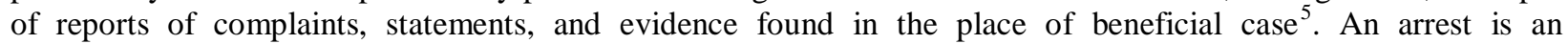
investigator's act of temporary restraint of suspect or defendant's freedom when there is sufficient evidence for the purpose of investigation or prosecution and / or justice. ${ }^{6}$ Although there has been early evidence to corroborate the alleged perpetrators of crimes, they remain domiciled as human beings with rights that should not be violated. Especially if for his actions there is no judge's decision to declare the offender. The purpose of providing legal protection to the perpetrator of the crime is to respect the human rights of the perpetrator of the crime, the legal certainty of the perpetrator and avoid the abuse of power. Nowadays people thought that with the prosecution of perpetrators of criminals then the protection of perpetrators is considered already completed. ${ }^{7}$

Suspects in the process of examination conducted by the investigator have the right to give information freely, must be kept away from fear. This provision is clearly contained in article 52 of the Criminal Procedure Code, which basically states that the purpose of the preliminary investigation by the investigator not to obtain the accused of the suspect but to gather information from the suspect regarding the existence of a criminal incident. But behind the authority of the investigator, in practice there are often cases of illegal detention, such as:

1. Gorontalo in 2002 where a couple of husband and wife Risman Lakoro and Rostin Mahaji were allegedly indicted for the murder of their biological daughter Alta Lakoro and finally sentenced to 3 years in prison but several years later after they were sentenced to a criminal, their daughter back home in good health. ${ }^{8}$

2 Didik M. Arief Mansur dan Lisatis Gustom, 2008, Urgensi Perlindungan Korban Kejahatan Antara Norma dan Realita, Jakarta, PT Raja Grafindo, p. 23

3 United Nation A/RES/40/34, 1985, Declaration of Basic Principles of Justice for Victims of Crime and Abuse of Power, Art. 1

4 Ibid, Art. 18

5 Law No. 8 of 1981 on Criminal Law Code (KUHAP), Article 17 jo. Article 1 (14)

Ibid, Art. 1 (20)

Didik M. Arief Mansur dan Lisatis Gustom, 2008, Op.Cit., p. 20

8 Accessed from http://news.liputan6.com/read/144214/risman-lakoro-akan-menggugat-polisi, $11 / 10 / 2015$ 
2. Jombang in 2008 where Kemat and his two friends were made a suspect in the assassination case of Asrori, a corpse found in a sugar cane in Bandar Kedungmulyo Village, Jombang. All three have been convicted, 17 and 12 years respectively. But lately known corpse in sugarcane garden is Fauzin Suyanto not asrori as expected. Kemat and his two friends are also not proven to have killed Fauzin. ${ }^{9}$

3. Jakarta in 2013 where Andro Suprianto and Nurdin Prianto arrested by Metro Jaya Police on 30 June 2013 related to the discovery of a buster named Dicky who died in Cipulir, South Jakarta. But in 2014 the Supreme Court cut Andro and Nurdin off not guilty. ${ }^{10}$

For those who have already taken their liberty through the process of arrest, look forward to the free verdict (vrijspraak) of the judge. Yet the often-anticipated free verdict does not necessarily restore the conditions of these illegal captive victims as they once did. This will leave a big problem for the families left behind, especially if the defendant is the head of the family who must bear the economic burden of the family. These illegal capture victims have suffered tremendous losses such as loss of income and employment, the family is indirectly victimized by the environment due to the "criminal" label already embedded, and the torture and inner pressure inside the prison for days or even years. A person's right to claim compensation for unlawful arrest is a classical basic right guaranteed by law. This basic right is owned by every citizen and guaranteed by the government. ${ }^{11}$

The filing of a lawsuit compensation for a unlawful arrest imposed by law enforcement on this illegal arrest event has been set forth in Article 95 paragraph (1) of KUHAP and Government Regulation Number 92 of 2015 on the Second Amendment to Government Regulation Number 27 of 1983 on the Implementation of the Code Criminal Procedure Law. Under this rule, the amount of compensation may reach Rp 600,000,000 (six hundred million rupiahs) for the illegal capture victim resulting in the death of the previous rule whose amount of compensation is as high as Rp 3,000,000 (three million rupiah). The above amounts certainly can not recover the unlawful capture of the victim as it was behind the amount of the compensation is still a legal process that must be passed the pretrial and disbursement process through the Ministry of Finance is not simple and takes a long time. Author considers that there should be a clear assessment and restriction on the mechanism of compensation for victims of unlawful arrest in the criminal justice system.

Method of the Research:-

The research method used in this research is sosilogical jurisprudence method. This study is based on the nofmatif law (regulatory legislation), observing how the reactions and interactions that occur when the norm system works in society. This research was conducted in the Makassar District Court and the Ministry of Finance of the Republic of Indonesia precisely in the Office of the State Treasury Service of Makassar.

The following paper devided its sources into 2 (two) criteria, that is: (1) Primary materials (obtained through interviews and direct research with relevant parties); and (2) Secondary materials (obtained through literature studies by reading books, magazines, internet, newspapers and other academic publication relevant to the issue concerned). Data obtained both primary and secondary will be analyzed qualitatively then presented descriptively.

\section{Results and Discussion:-}

\section{Compensation for Unlawful Arrest Victims:-}

Indonesian law has been governed in Part One, Chapter XII of the Criminal Procedure Code against the claim for damages caused by arrest, detention, prosecution and trial or any other act, for no statutory reason or due to errors concerning the person or applicable law. The other measures referred to are losses incurred by home infestation, searches, and unlawful seizures by law. More firmly stipulated in Article 95 paragraph 5 that the examination of compensation follows pretrial events.

9 Accessed from http://nasional.news.viva.co.id/news/read/24348-13-polisi-dihukum-minta-maafpada-kemat-cs, 23/11/ 2015

10 Accessed from https://m.tempo.co/read/news/2016/08/03/064792945/pengamen-korban-salahtangkap-polda-cacat-dan-ditolak-kerja, 23/11/2016

11 C.S.T. Kansil, 1989, Pengantar Ilmu Hukum dan Tata Hukum Indonesia, Jakarta, Balai Pustaka. p. 120-121 


\section{Pretrial:-}

According to Dr. A. Hamzah, pretrial is a place for human rights violations because the intention of the establishment of pretrial is as a "translation" of habeas corpus ${ }^{12}$ which is the substance of human rights and the drafting of the Criminal Procedure Code is also much encouraged by international human rights law which has become International Customary Law. ${ }^{13}$ The notion of pre-trial is defined in Article 1 (10) of the Criminal Procedure Code. Pretrial is the authority of the district courts to examine and decide upon in accordance with the manner laid down in this law, concerning: (a) The legal or absence of an arrest and / or detention at the request of the suspect or his or her family or any other party on the suspect's power; (b) The legitimacy of an investigation or suspension of prosecution upon request for the sake of law and justice; and (c) A request for compensation or rehabilitation by a suspect or his or her family or other party for a proxy whose case is not brought to trial. The Constitutional Court through Decision No 21 / PUU-XII / 2014 has expanded the object of the Pretrial. Based on this ruling, the determination of suspects, searches, and foreclosures that previously did not include objects that could be promulgated, since the verdict was read, valid as a pre-trial object. This ruling has extended the pre-trial object previously only on the arrest, detention, suspension of investigation or cessation of prosecution. As stated above, the purpose of this pretrial institution is to control or supervise the proceedings of criminal procedure law in order to protect the rights of suspects or defendants. The control is done in the following ways: ${ }^{14}$ (a) Vertical controls, ie controls from the top down and (b) Horizontal Control, ie lateral control, between the investigator, the reciprocal general and the suspect, his family or a third party.

Pretrial proceedings are regulated in Article 82 of the Criminal Procedure Code. In the pre-trial hearing there are two parties, namely the party applying for the pretrial hearing, referred to as the Petitioner or the Petitioners. The applicant or the Petitioners may act alone or represented by their proxy. The other party shall be the party to which the pre-trial hearing is requested, referred to as the Respondent, which if more than one is called Respondent I, Petitioner II, and so on. In the request of a pretrial hearing filed, as a pretrial petitioner is his institution, so acting for and on behalf of the institution is its leader. Regarding the pretrial hearing is stipulated in Article 82 paragraph (1) of Criminal Procedure Code, as follows: (a) Within 3 (three) days after receipt of the request for a pre-trial hearing, the appointed judge shall establish the day of the hearing; (b) In examining and deciding whether or not an arrest or detention shall be valid, whether or not a suspension of an investigation or prosecution, a request for compensation or rehabilitation resulting from the unlawful arrest or detention, suspension of investigation or prosecution and any seized items not included in the evidence, Hear information from either the applicant or the requested party; (c) The examination shall be carried out appropriately and no later than seven days the judge shall have rendered his verdict; (d) In the event that a case has already been investigated by the district court, while the examination of the request to the pretrial has not been completed, the request shall be terminated; and (e) Pretrial rulings at the investigation level do not rule out the possibility of conducting pretrial hearings again at the level of examination by the claimant, if it is submitted a new request. The pretrial hearing is chaired by a single judge appointed by the President of the District Court assisted by a clerk (Article 78 paragraph (2) of the Criminal Procedure Code).

Compensation is the right of a person to obtain the fulfillment of his claim in the form of remuneration of money for arrest, detention, prosecution or trial for no reason under the law or by mistake concerning the person or law applied in the manner prescribed by law (Article 1 paragraph (22) of the Criminal Procedure Code). The rules on the amount of compensation have been renewed in accordance with Article 9 of the Government Regulation No. 92 of 2015 on the Second Amendment to Government Regulation No. 27 of 1983 on the Implementation of the Criminal Procedure Code. Changes in the amount of compensation from the previous regulation of Government Regulation No. 27 of 1983 can be quite significant. The changes can be seen from the following table:

12 Habeas Corpus grants a person the right to pass a court order demanding that the detaining officer (police or prosecutor) prove that the detention is unlawful (or illegal) or strictly legal in accordance with applicable law. This is to ensure that the deprivation or restriction of independence against a suspect or defendant has fully complied with applicable laws and human rights guarantees.

13 Luhut M.P. Pangaribuan, 2006, Hukum Acara Pidana Surat-surat Resmi di Pengadilan oleh Advokat (Praperadilan, Eksepsi, Pledoi, Duplik, Memori Banding, Kasasi, Peninjauan Kembali), Jakarta, Djambatan, p. 20

14 Moch. Faisal Salam, 2001, Hukum Acara Pidana dalam Teori \& Praktek, Bandung: Penerbit Mandar Maju, p. 322 
Tabel 1:- Comparison of the Amount of Compensation Between Government Regulation No. 27 of 1983 and Government Regulation No. 92 of 2015

\begin{tabular}{|l|c|c|c|c|}
\hline \multirow{2}{*}{ Category } & \multicolumn{2}{|c|}{$\begin{array}{c}\text { Government Regulation No. 27 of } \\
\text { 1983 }\end{array}$} & \multicolumn{2}{c|}{ Government Regulation No. 92 of 2015 } \\
\cline { 2 - 5 } & Minimum & Maximum & Minimum & Maximum \\
\hline $\begin{array}{l}\text { A person whose criminal case } \\
\text { are terminated at the level of } \\
\text { investigation or prosecution }\end{array}$ & Rp 5.000,- & Rp 1.000.000,- & Rp500.000,- & Rp100.000.000,- \\
\hline $\begin{array}{l}\text { Suspects, defendants or } \\
\text { convicted persons arrested, } \\
\text { detained, prosecuted and tried } \\
\text { or subjected to other acts, for } \\
\text { no reason under the law or for } \\
\text { errors concerning the person } \\
\text { or applicable law }\end{array}$ & Rp 5.000,- & Rp 1.000.000,- & Rp500.000,- & Rp100.000.000,- \\
\hline $\begin{array}{l}\text { Arrest, detention and other } \\
\text { acts that result in illness or } \\
\text { disability so can not work }\end{array}$ & - & Rp 3.000.000,- & Rp 25.000.000,- & Rp 300.000.000,- \\
\hline $\begin{array}{l}\text { Arrest, detention and other } \\
\text { actions that result in death }\end{array}$ & & Rp 3.000.000,- & Rp 50.000.000,- & Rp 600.000.000,00 \\
\hline
\end{tabular}

Source: Primary data, 2017 (edited)

\section{The Compensation Mechanisms for Unlawful Arrest Victims:-}

The struggle of unlawful arrest victims does not stop after getting pretrial verdict. Efforts to obtain justice still continue at the stage of payment of compensation. This can be seen in one of the victims of the illegal arrest, Andro Suprianto and Nurdin Prianto, represented by his legal counsel Bunga Siagian S.H. Who has obtained pre-trial stipulation from August 9, 2016 where the applicant is entitled to a compensation of Rp 72,000,000 (Seventy two million rupiah) but until March 2017 has not received any such compensation payment. Based on the telephone interview with the victim's legal counsel ${ }^{15}$, Bunga Siagian S.H. Stated that after obtaining a copy of the decision of the court and bringing it to the Ministry of Finance of the Republic of Indonesia, they received no response at all and then returned to the local district court, and were directed to the Attorney but the prosecutor's office refused because no legal basis for them to pay the compensation. The next effort they take is to ask the Ombudsman ${ }^{16}$ in the hope of obtaining an enlightenment regarding the payment of compensation in accordance with the judgment they have obtained.

Government Regulation No. 92 of 2015 on the Second Amendment to Government Regulation Number 27 of 1983 on the Implementation of the Criminal Procedure Code has stipulated that the payment of compensation shall be made by ministers who administer government affairs in finance. Furthermore, payment of compensation shall be made within a period of no more than 14 (fourteen) working days from the date of application for compensation received by the minister in charge of government affairs in the field of finance and the provisions concerning the procedure of payment of compensation shall be governed by a Ministerial Regulation governing the affairs of the government In finance. If it is associated with the above case then certainly Government Regulation No. 92 of 2015 has not been implemented.

Regulations on the procedure for payment of compensation shall be regulated in Decree of the Minister of Finance of the Republic of Indonesia Number 983/KMK/01/1983. As of this government regulation was adopted on December 8, 2015 until April 2017, the ministerial regulation on the procedure for the compensation payment has

15 Interview on 24 February 2017

16 The Ombudsman of the Republic of Indonesia is a state institution in Indonesia which has the authority to oversee the implementation of public services both organized by state and government officials, including those held by State-Owned Enterprises, Regional Government Enterprises and Legal Entities State Owned as well as private entities or individuals assigned to perform certain public services that part or all of their funds are sourced from the State Revenue and Expenditure Budget or the Regional Revenue and Expenditure Budget. 
not been updated. If it refers to Decree of the Minister of Finance of the Republic of Indonesia Number 983/KMK/01/1983, the mechanisms of compensation for the victim of unlawful arrest are:

1. Chairman of the local District Court applying for the provision of funds to the Minister of Justice cq. The Secretariat General of the Department of Justice by enclosing the determination of the courts;

2. Based on the request, the Minister of Justice cq. Secretariat General of the Ministry of Justice every quarter or every time it is required to submit a request for the issuance of an Organizational Decree (SKO) to the Minister of Finance cq. The Director General of the Budget shall be accompanied by a copy of the determination of the Court on which it is based;

3. Minister of Finance cq. The Director General of Budget issues a SKO on the financing charges and calculation of routine state budget;

4. The SKO shall be submitted to the unlawful arrest;

5. The victim shall file a request for payment to the State Treasury Office (KPN) through the Chairman of the Local District Court, by enclosing the SKO and the determination of the court;

6. Chairman of the local District Court shall forward the application to KPN accompanied by a Payment Request Letter (SPP);

7. KPN shall issue a Pay Order (SPM) to the eligible; and

8. The decision of the court shall be returned to the victim after the stamp has been made a payment.

The above rule is not in line with Government Regulation No. 92 of 2015, the process is very convoluted and takes a long time when in Article 11 paragraph (2) has stipulated that payment of compensation shall be made within a period of maximum 14 (fourteen) working days Commencing from the date of application for compensation shall be received by the minister who administers government affairs in the field of finance.

Based on the results of interviews with officials of KPPN Makassar II, Eka Yudha Utama, Wahyu Dwi Ariadi and Head of KPPN Makassar II, Wempi ${ }^{17}$ principally stated that the above rules have been missed proved by the use of several terms that have undergone changes based on Law No. 1 of 2004 on Treasury State and Regulation of the Minister of Finance of the Republic of Indonesia Number 190/ PMK.05/2012 concerning Payment Procedures in the Framework of the Implementation of the State Revenue and Expenditure Budget. Some of the changes in question are:

a. Ministry of Law and Human Rights in Decree of the Minister of Finance of the Republic of Indonesia Number 983 / KMK / 01/1983 changed to Supreme Court

b. Organizational Decree (SKO) changed to revised DIPA (List of Budget Implementation Entry)

KPPN Kota Makassar claimed to be unusual to handle the request for compensation by the victim of unlawful arrest and even thought that they were not authorized in that case until the author showed a copy of Government Regulation Number 92 of 2015. After reading the rule then they can describe the procedure of payment of compensation based on Decree of the Minister of Finance of the Republic of Indonesia Number 983/KMK/01/1983 by following the development of the work of KPPN and the Ministry of Finance of the Republic of Indonesia, namely:

1. Chairman of the local District Court applying for the provision of funds to the Supreme Court of the Republic of Indonesia;

2. Based on the petition, the Supreme Court of the Republic of Indonesia submits a request for issuance of the DIPA Revision to the Minister of Finance cq. The Director General of the Budget shall be accompanied by a copy of the determination of the Court on which it is based;

3. Minister of Finance cq. The Director General of Budget issues the DIPA Revision on the financing charges and calculation of the routine state budget;

4. The revised DIPA shall be submitted to the illegal fishing entrants;

5. The victim shall file a request for payment to the State Treasury Office (KPN) through the Chairman of the Local District Court, attaching the DIPA Revision and the determination of the court;

6. The Head of the local District Court shall forward the application to KPN accompanied by a Payment Request Letter (SPP);

7. KPN shall issue a Pay Order (SPM) to the eligible; and

8. The decision of the court shall be returned to the victim after the stamp has been made a payment.

17 Interview on 2 March 2017 
If the above rules can be applied properly then KPPN Makassar II states that the above compensation mechanism can be settled within 14 days as mandated by Government Regulation No. 92 of 2015.

The Efectivity of Indonesian Regulation on The Compensation Mechanisms for Unlawful Arrest Victims:The effective legal indicator is when what is designed can be realized. The mechanism based on the Decree of the Minister of Finance of the Republic of Indonesia Number 983/KMK/01/1983 still shows a complicated procedure and requires the role of the victim in obtaining his rights such as, the victim is required to apply for payment to the State Treasury Office through Chairman of the Local District Court, by attaching the DIPA Revision and the determination of the court. In accordance with the Government Regulation No. 92 of 2015 on the second amendment to Government Regulation No. 27 of 1983 on the Implementation of the Criminal Procedure Code as amended by Government Regulation Number 58 of 2010 on Amendment to Government Regulation Number 27 of 1983 on the Implementation of the Book The Criminal Procedure Law is conducted by the Government in order to fulfill the sense of justice, equilibrium, benefit, legal certainty, and humanity for the victims. As for some substances that made changes, among others, the amount of compensation and the process of payment of compensation to the applicant for compensation.

The draft on Government Regulation No. 92 of 2015 has not been fully realized, namely, certainty in the process of payment of compensation to the applicant for damages. Due to the convoluted procedure some victims of illegal arrest prefer not to demand their rights because they do not want to be involved longer with legal procedures that must be bypassed. This is in line with the interviews of Abdul Razak, S.H, ${ }^{18}$ a lawyer who has handled several unlawful arrest cases several times. According to him some of his clients after being informed of his right to obtain compensation for his legal actions, did not want to claim compensation for not wanting to go through a procedure that is convoluted and takes a long time. Victims of illegal arrest only want to be free and go back to running their activities.

Fulfillment of compensation Victims of illegal arrest are strongly concerned with legal factors, law enforcement, supporting facilities or facilities, community and livelihood factors. Government Regulation No. 92 of 2015 has been present as legal protection against unlawful arrest victims with significant changes in the amount of compensation but unfortunately until now not yet equipped with rules on payment mechanism of compensation. Law enforcement officers play a very important role as implementers of the rules that have been made, but unfortunately based on the results of the study done by author some officials still do not know the existence of Government Regulation No. 92 of 2015 such as judges Bonar Harianjo, S.H., M.H. ${ }^{19}$ and an officer of KPPN Makassar II who claimed not to know the regulation.

\section{Conclusions:-}

KUHAP as Indonesian criminal law code has been governed that anyone who has been the victim of unlawful arrest, detention, prosecution, and trial or any other act, for no statutory reason or due to errors concerning the person or applicable law shall have an enforceable right to compensation. Further regulated that the examination of compensation follows pre-trial. After receiving the determination of the court, based on the Decree of the Minister of Finance of the Republic of Indonesia Number 983/KMK/01/1983 on the Procedure of Payment of Indemnification adjusted with Law No. 1 of 2004 on State Treasury and The Regulation of the Minister of Finance of the Republic of Indonesia Number 190/PMK.05/2012 on Payment Procedures in the Framework of the Implementation of the State Budget of Revenue and Expenditure, the mechanism for payment of compensation for victims of unlawful arrest is as follows: (1) The Head of the local District Court filed a request for provision of funds to the Supreme Court of the Republic of Indonesia; (2) Based on the request, the Supreme Court of the Republic of Indonesia shall submit a request for issuance of the DIPA Revision to the Minister of Finance cq. The Director General of the Budget shall be accompanied by a copy of the determination of the Court on which it is based; (3) Minister of Finance cq. The Director General of the Budget issues the DIPA Revision on the financing charges and calculation of routine state budget; (4) The revised DIPA shall be submitted to an illegal fishing entrant; (5) The victim shall file a request for payment to the State Treasury Office (KPN) through the Chairman of the Local District Court, by enclosing the DIPA Revision and the determination of the court; (6) The Head of the local District Court shall forward the application to KPN accompanied by a Payment Request Letter (SPP); (7) KPN shall issue a Pay Order (SPM) to the eligible; And (8) The decision of the court shall be returned to the victim. The

18 Interview on 23 February 2017

19 Interview on 27 February 2017 
Ministry of Finance of the Republic of Indonesia should immediately review Indonesia Regulation on the mechanism for Payment of Compensation because it is no longer applicable in accordance with some other rules in Indonesia.

\section{References:-}

1. Achmad Ali. 2009. Menguak Teori Hukum (Legal Theory) dan Teori Peradilan (Judicialprudence): Termasuk Interpretasi Undang-Undang (Legisprudence), Jakarta: Kencana.

2. Andi Hamzah. 2012. Hukum Acara Pidana Indonesia, Jakarta: Sinar Grafika.

3. Andi Sofyan. 2013. Hukum Acara Pidana Suatu Pengantar, Yogyakarta: Rangkang Education.

4. Bernard L. Tanya. 2003. Teori Hukum (Strategi Tertib Manusia Lintas Ruang dan Generasi). Semarang: Genta Publising.

5. C.S.T. Kansil. 1989. Pengantar Ilmu Hukum dan Tata Hukum Indonesia. Jakarta: Balai Pustaka.

6. Didik M. Arief Mansur dan Lisatis Gustom. 2008. Urgensi Perlindungan Korban Kejahatan Antara Norma dan Realita. Jakarta: PT Raja Grafindo.

7. Handar Subhandi Bakhtiar. Custody Services of The Human Rights Perspective. Journal of Research in Humanities and Social Science. Volume 5 Issue 4 (2017) pp: 48-51

8. Jimly Asshiddiqie. 2010. Konstitusi \& Konstitusionalisme Indonesia, Jakarta: Sinar Grafika.

9. Luhut M.P. Pangaribuan. 2006. Hukum Acara Pidana Surat-surat Resmi di Pengadilan oleh Advokat (Praperadilan, Eksepsi, Pledoi, Duplik, Memori Banding, Kasasi, Peninjauan Kembali), Jakarta: Djambatan.

10. Martiman Prodjohamidjojo. 1982. Penangkapan dan Penahanan, Jakarta: Ghalia Indonesia.

11. Moch. Faisal Salam. 2001. Hukum Acara Pidana dalam Teori \& Praktek, Bandung: Penerbit Mandar Maju.

12. Muhammad Said Karim. 2012. Tugas dan Fungsi Advokat Selaku Pemberi Bantuan Hukum Dalam Perkara Pidana, Makassar: Kretakupa Print.

13. Mukti Fajar dan Yulianto Achmad. 2015. Dualisme Penelitian Hukum Normatif dan Empiris. Yogyakarta: Pustaka Pelajar.

14. Nawawi. 1987. Teknik dan Strategi Membela Perkara Pidana. Jakarta: Fajar Agung.

15. Peter Mahmud Marzuki. 2008. Pengantar Ilmu Hukum. Jakarta: Kencana.

16. Robert Audi. 1995. The Cambridge Dictionary of Philosophy. Cambridge: Cambridge University Press.

17. Satjipto Raharjo. 1986. Ilmu Hukum. Bandung: Alumni.

18. Salim dan Erlies Septiana Nurbani. 2014. Penerapan Teori Hukum Pada Penelitian Tesis dan Disertasi. Jakarta PT Raja Grafindo Persada

19. Yahya Harahap. 2002. Pembahasan Permasalahan dan Penarapan KUHAP. Jakarta: Sinar Grafika. 